\title{
Female students' Attitudes at Faculty of Physical Education towards the Use of Hybrid Learning to study the Gymnastics Course under Covid-19 pandemic
}

\section{Eman Kamal El-Din Ibrahim}

Assistant Professor, Department of theories and applications of gymnastics, exercises and sports performances, Faculty of Physical Education, Sadat City University

Abstract

The research aims to designing a questionnaire to identify the students' attitudes at Faculty of physical Education towards the Use of Hybrid Learning to study the Gymnastics Course under Covid-19 pandemic, the researcher used descriptive method to answer the research questions, The researcher selected the research sample from(200) female students were chosen randomly, (50\%) of the total population of the study community, the most important result The study sample members from the Faculty of Physical Education have a very positive attitude towards the First Theme phrases "Awareness of Hybrid Learning system for Gymnastics Course" with an arithmetic mean of (4.239 out of 5) placed in the first category of the five-point scale (from 4.2 or more); the category that indicates the "Strongly Agree" option in the study tool. This indicates that the study sample members have a positive attitude towards Hybrid Learning.

\section{Introduction and Research Problem}

The educational process has been recently facing a real challenge under Covid-19 pandemic. That threatens its security and integrity, not only intellectually and cognitively but also humanly. As the entire human element involved in the learning community has been affected; including the teacher, student, administrator and all those who are running the education life. Since education and learning process is a life continuous inexhaustible wellspring, most countries throughout the world have tended to confront this challenge and maintain the educational process by providing a new form of education, which is e-learning. Countries success has varied in applying this new form of the educational process with regard to; ensuring the provision of well-established infrastructure, qualified cadres, proper educational curricula, interactive and communicative programs, in addition to the employment of electronic platforms and digital content preparation...etc.

With the spread of Covid-19 virus throughout the world, and in order to limit its spread world-widely, most countries have taken many important procedures that help protecting sibling of school and university students. Distance education or e-learning was imposed as an attempt to hold down that wide spread of the pandemic. Hence, this is what made distance education to be the tended choice. But, in fact, whatever happens, both formal education and direct contact between the teacher and the learner are indispensable. Therefore the actual role of the school and the university is fundamentally essential throughout ages, regardless of any kind of progress.(24)

In Egypt, The actual state of education indicates that the e-learning was not very well established in the past. Moreover, most of university students were not trained to it. That was Due to the predominance of the traditional education as well as the lack of full use of technology and its tools, or their ineffective use.

So that during applying and practicing the e-learning separately from the traditional methods, problems have emerged. For instance, e-learning encourage the students' introversion as they are deprived from a real educational environment of an actual interaction. Such lack of interaction negatively affect learners' social communication skills. In like manner, the multi- 
sensory learning modal is neglected in e-learning; rather only hearing and sight are used. Also the confined teacher-student natural human relations causes learners to be hardly satisfied and motivated. On the other hand, E-learning is inappropriate for some kinds of curricula and educational courses. In addition, many students still prefer the traditional method and attending face to face lectures. Also the difficulty in conducting the evaluation process and its credibility cannot be denied; especially when the course contains practical performance skills. Consequently, these problems have given rise to the need for a new education system that combines the advantages of e-learning and the advantages of traditional learning, which is the so-called Hybrid Learning. (2:21)

In light of challenges and crises imposed by Covid-19 pandemic, Ministry of Higher Education has made the decision to suspend study on the fifteenth of March of the year 2020, the academic courses to be completed through distance education, then return again by June of the same year to complete the final exams' work for University students. On the seventeenth of October, the Ministry announced a plan to implement the Hybrid Learning system in the Egyptian universities with the start of the current academic year. The system is based on the integration between both face-to-face and distance education. Thereupon, student intensity is to be reduced, making the most benefits of Faculty staff members experience and university infrastructure is to be achieved. As part of the measures taken by universities around the world to confront Covd-19 virus, each university sets the necessary mechanisms and required procedures in order to implement the system in accordance with the nature of the different faculties and programmers.

The use of the Hybrid Learning system is the real future gateway to education. It is the most effective and powerful alternative among the educational options available, which increases the opportunities for use and communication, to face the repercussions of covid-19 crisis on the university education sector, to avoid interruption and suspension of education as well.

Hybrid Learning is a form of digital education that combines elements of online education, traditional face-to-face education, synchronous and asynchronous education as well as offering many benefits to the student, faculty and university. (21:219)

Hybrid Learning system allows the transfer of information through direct face-to-face learning channels and online learning platforms, which in turn changes how students access and learn information. In addition to the abovementioned, Hybrid Learning courses transform the student-teacher interactions into online ones reducing the amount of direct face-to-face interactions which is significantly copes with the urgent changes particularly Covid-19 pandemic. Moreover, Hybrid Learning brings together more than one method and tool for learning, whether electronic or traditional. Hybrid Learning provides a new good quality of learning that meets each learner's characteristics and needs, fits the nature and educational objectives of the subjects, and develops learners' interactive skills in dealing with the scientific material provided to them. Hybrid Learning also creates an atmosphere of intimacy between the teacher and his students, whether through online or face-to-face interaction in the classroom.

Gymnastics is one of the curricular subjects offered to female students at Faculty of Physical Education, which includes various practical skills on the four Gymnastics Apparatus (the floor Exercise - uneven Bars - vault table - balance beam). In addition to the practical part comes the theoretical content teaching of the gymnastics course, which was affected by the challenges and repercussions of the spread of the new Covid-19 virus the country has been facing. Therefore, using modern scientific methods in teaching the course is badly required to 
achieve its objectives in providing learners with better skillful performance of exercise routines and better understanding of the theoretical part under the current conditions and challenges of the pandemic.

Knowledge the individuals' attitudes is crucial, as they provide them with the capacity to adapt with many several situations they face; to harmonize their behavior and persistence relatively in different situations, and they are linked to their needs and motivations. Whereas such attitudes are the important and crucial factors in determining the students' position at this critical age stage, coming on the labour market, it has become necessary to identify the nature of these attitudes and the influencing factors on them. Such identification paves the way for the educational institutions to properly direct these attitudes to serve as a powerful driver creating the best learning situations that can upgrade the level of the educational process. (4:101)

Successful education also depends on positive attitudes towards it, i.e. if the students have positive attitudes towards modern education systems, they can gain knowledge and experience in the regard of learning related to cognitive skills. (13:354)

Despite the several pros of Hybrid Learning, sudden switch to its use in teaching may lead many students to be shocked and tensioned personally.

The researcher noticed a difference in the extent to which female students accept the use of Hybrid Learning to study the gymnastics course as it is a modern method that they did not use before, So the researcher, through this study, seeks to explore the female students' attitudes at the faculty of physical Education towards using Hybrid Education to study the Gymnastics Course under Covid-19 pandemic. Since their attitudes have a great impact on their acceptance to concepts and experiences of the subject matter and thus surely affects their learning outcomes. So that decision makers are to be able to take these attitudes and opinions into account to facilitate the teaching and learning process. Students of positive attitude towards Hybrid Learning are more likely to achieve success than those of negative attitude. Educational institutions bear great responsibility for changing and directing the individuals' attitudes in general and their students in particular towards many important fields, including the area of learning methods and ways development; first of all is Hybrid Learning.

\section{Research Objective}

Designing a questionnaire to identify the students' attitudes at Faculty of physical Education towards the Use of Hybrid Learning to study the Gymnastics Course under Covid-19 pandemic.

\section{Research question}

What are the students' attitudes at Faculty of physical Education towards the use of Hybrid Learning to study the Gymnastics Course under Covid-19 pandemic?, Through the following themes:

- Female students' Awareness of Hybrid Learning system to study the Gymnastics Course.

- Female students' impressions towards the use of Hybrid Learning to study the Gymnastics Course.

- The importance of Hybrid Learning for studying the Gymnastics Course.

\section{Research Expressions}

\section{Attitude:}

A state of psychological and neural readiness, developed through personal experiences. It has a directive or dynamic relevance to the individual's response to all stimulus subjects and situations that trigger this response. (16:6) 


\section{Hybrid Learning:}

An educational pattern that includes an effective integration of educational multimodalities, utilizing the traditional education alongside e-learning, in order to obtain their best features altogether. (17:200)

\section{Research Methodology}

The descriptive approach was used, in order to answer the research questions. Whereas the descriptive approach is based on collecting data and information related to the phenomenon under study, in order to describe, analyze and explain it through interrogating a sample of the research community.

\section{Research community}

The research community consisted of the first year female students at the Faculty of Physical Education, Sadat City University, who studied the Gymnastics Course for the first and second semesters under the Hybrid Learning system in the academic year 2020 AD / 2021 AD, the number of students was (400) female students.

\section{Research Sample} community.

(200) female students were chosen randomly, (50\%) of the total population of the study

Also, a number of (25) female students were selected from the same research community and outside the basic sample in order to conduct the scientific parameters (consistencyreliability) for the questionnaire under the research.

\section{Research Tool}

It was relied upon the questionnaire done by the researcher (Appendix 3) as a tool for collecting data after making sure that it achieved the scientific parameters, as it is the best mean to gather information about opinions and attitudes, and due to the easiness of its classification and analysis.

Steps of designing the questionnaire about the students' attitudes of the Faculty of Physical Education towards the use of Hybrid Learning to study the gymnastics course under Covid-19 pandemic. Appendix (5)

The questionnaire included three axes, the first axis included 16 phrases, the second axis contained 20 phrases, and the third axis contained 19 phrases, with a total of 55 phrases within the questionnaire as a whole.

\section{Applying the Research to Practice}

The questionnaire was distributed to the research sample in the period from Saturday 29/5/2021AD to Wednesday 2/6/2021AD. And two groups per day (40) students to answer the questionnaire.

\section{The statistical methods used}

Based on the nature of the study and objectives demanded, the (SPSS) program was used, based on the following statistical methods:

1- Pearson correlation coefficient.

2- Cronbach's alpha coefficient.

3- Frequencies and percentages.

4- Averages.

5- Standard deviations. 


\section{Research results \\ Firstly: Presentation and discussion of the first theme results \\ Table (1)}

Ordering the phrases according to the students' attitude score towards the first theme phrases 'Female students' awareness of the Hybrid Learning System to study the Gymnastics Course'

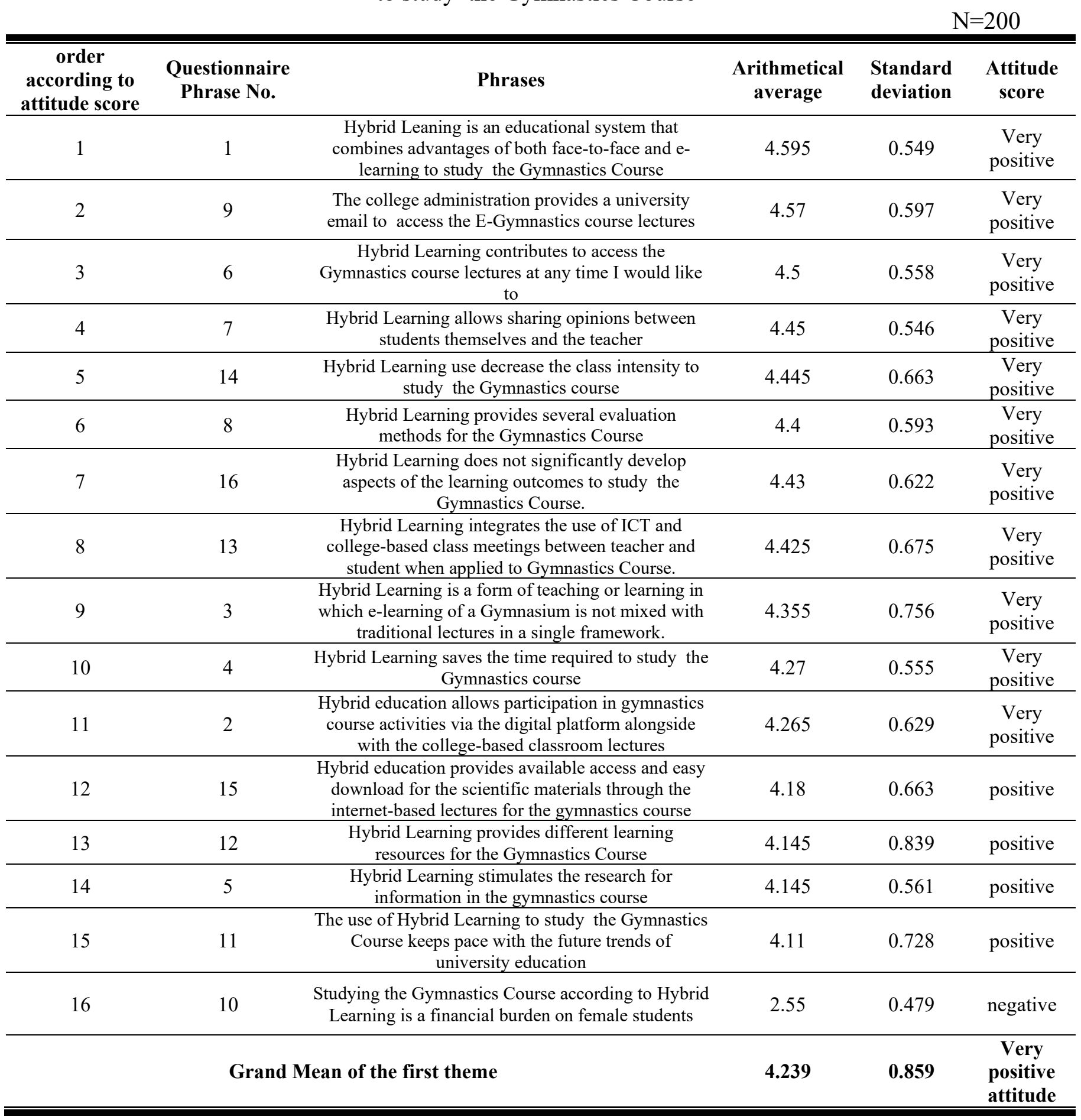


Table (1) demonstrates that the study sample members at Faculty of physical Education have a very positive attitude towards awareness of the Hybrid Learning system for studying the Gymnastics Course with an arithmetic average of (4.239 out of 5), which is an average that falls in the first category of the five-scale categories (from 4.2 and more). It is the category that indicates the "Very Agree" option in the study tool, which means that the study sample members have a tendency towards Hybrid Learning.

Table No. (1) Also shows that the score of students' attitudes towards the first theme phrases arranged from No. 1 to No. 11 were at the very positive level; as the arithmetic average is (4.595 to 4.265), which comes in the first of the five-scale categories. That category indicates the very positive attitude of the sample members towards awareness of the Hybrid Learning system for studying the Gymnastics Course.

Phrases No. 12 to No.15 also fall in the positive level, where the arithmetic averages ranged (from 4.18 to 4.11 ), which belong to the second category of the five-scale categories. This second category is the one that refers to the sample members' positive attitude towards the Hybrid Learning system to study the Gymnastics course. This abovementioned result can be explained in the light of sample members' sufficient awareness of Hybrid Learning pros and cons of its use to study the gymnastics course under Covid-19 pandemic. One of the most prominent advantages of Hybrid Learning is that it combines between face-to-face and e-learning advantages to study the course. So far the students have studied this course for a whole year via this system. Actually they got benefits of the advantages it provides.

The college administration also provided a university email to access the electronic Gymnastics Course lectures, which enabled the students to get lectures at any time they would like. Moreover, student can express their opinion regarding these lectures content, discuss and participate with colleagues as well as the lecturer him/herself. Additionally, Hybrid Learning reduced the students' intensity inside the college-based lectures. That provided with a suitable atmosphere for the precautionary measures to be efficiently followed under Covid019 crisis. This system also offered other evaluation methods, like the e-exams in Gymnastics which have never been used before. Furthermore, it reduced the time required for the college-based-classroom study.

Through the use of the Hybrid Learning system, female students were able to easily download the scientific materials delivered on the Gymnastics e-lectures. Many various learning sources were available, which motivated the students to search for information. This was positively reflected in the scores of the female students' attitude toward the first theme phrases. This awareness is necessarily an outcome of the College sincere concern to comply with the Ministry of Higher Education's plan applied throughout universities to address Covid-19 crisis. The ministry plan approved the use of Hybrid Learning in the Egyptian universities. The awareness about the use of Hybrid Education System in the college was widely spread through the preparation of a manual-guide. Moreover, all the college students were publicly notified by the use of the system on all the social media websites.

Phrase No.16 comes in the negative level at an arithmetic average of (2.55), which is an arithmetic average of the fourth category of the five-scale categories. This category indicates the sample members' negative attitude towards this phrase; because the students see that studying the gymnastics course according to Hybrid Learning system formed a financial burden on them. This financial burden was due to the necessity of providing a consistent internet access in order to attend the e-lectures, which required the necessity of affording financial sums so that guarantee the students' regular attendance in the online lectures during the academic year. 
This is consistent with the findings by "Sabreen Mahmoud" (2021) (8) that attending online lectures drops a financial loads on families shoulders as they are obligated to provide an appropriate environment; such as purchasing devices, providing additional Internet subscriptions to attend e-learning events at a distance.

"Hybrid Learning is defined as an educational system that makes use of all media and technology means, by combining more than one method and tool for learning, whether electronic or traditional. So that, a commensurate learning that meets the characteristics and needs of the learners can be provided on one hand, and meets the academic course nature and the educational objectives on the other hand" stated by Tayseer Alkelani. (50:3)

This is also consistent with the study results by "Slavkin Slavkin" (2005) (23), "Majdi Ali" (2012) (12), "Hatik and Narcivin Hatice and Narcivin" (2019) (22), "Ibrahim Abdullah" (2021) (1) regarding the students' knowledge and awareness of the hybrid education system, and that most students fully understand the concept of Hybrid Learning objectives.

\section{Second: Review and Discussion of the Results of Theme Two}

Table (2)

Order of Phrases according to the Score of Students' Attitudes towards Theme Two Phrases

"Students' Impressions towards the Use of Hybrid Learning in Gymnastics Course"

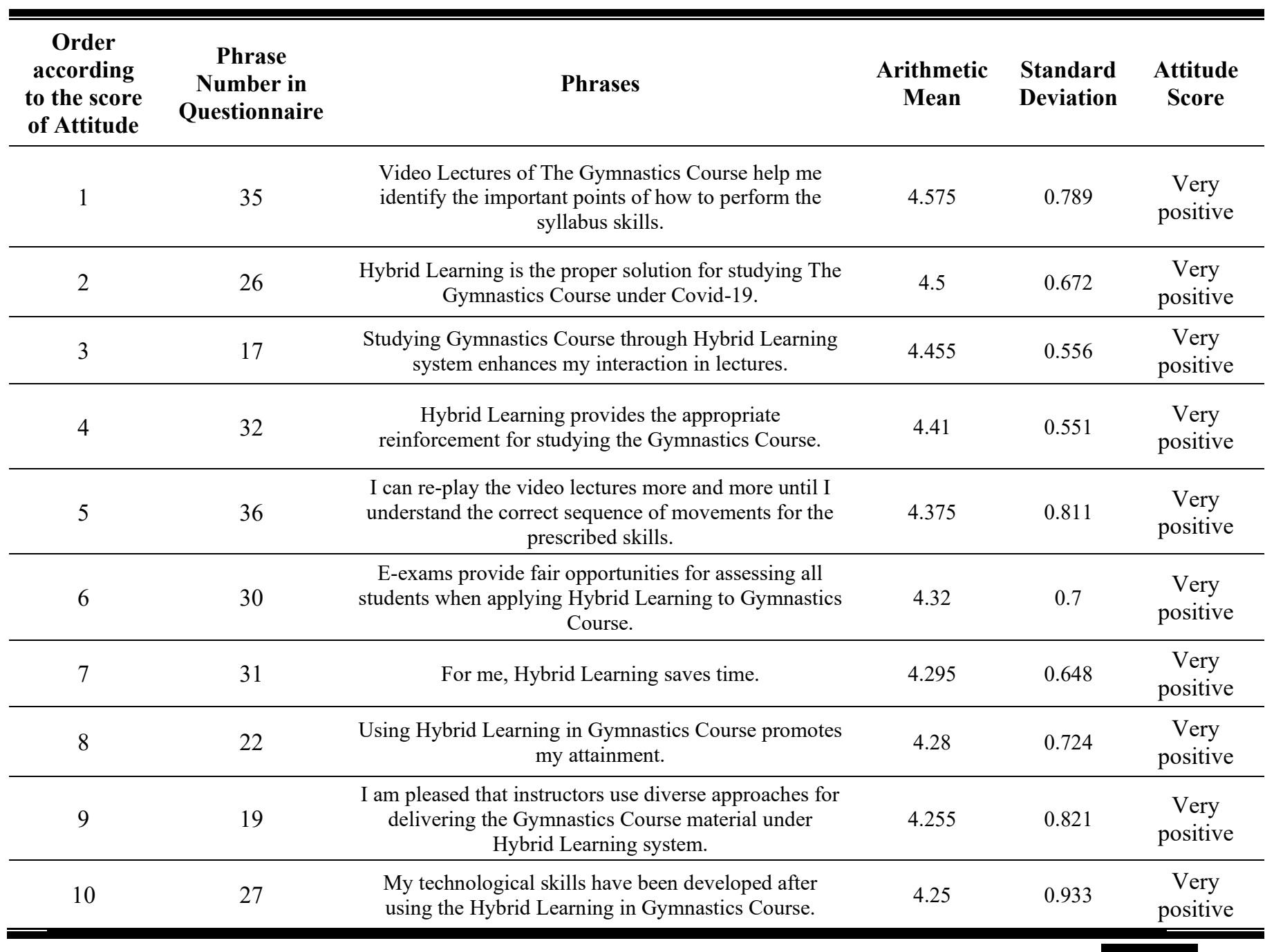




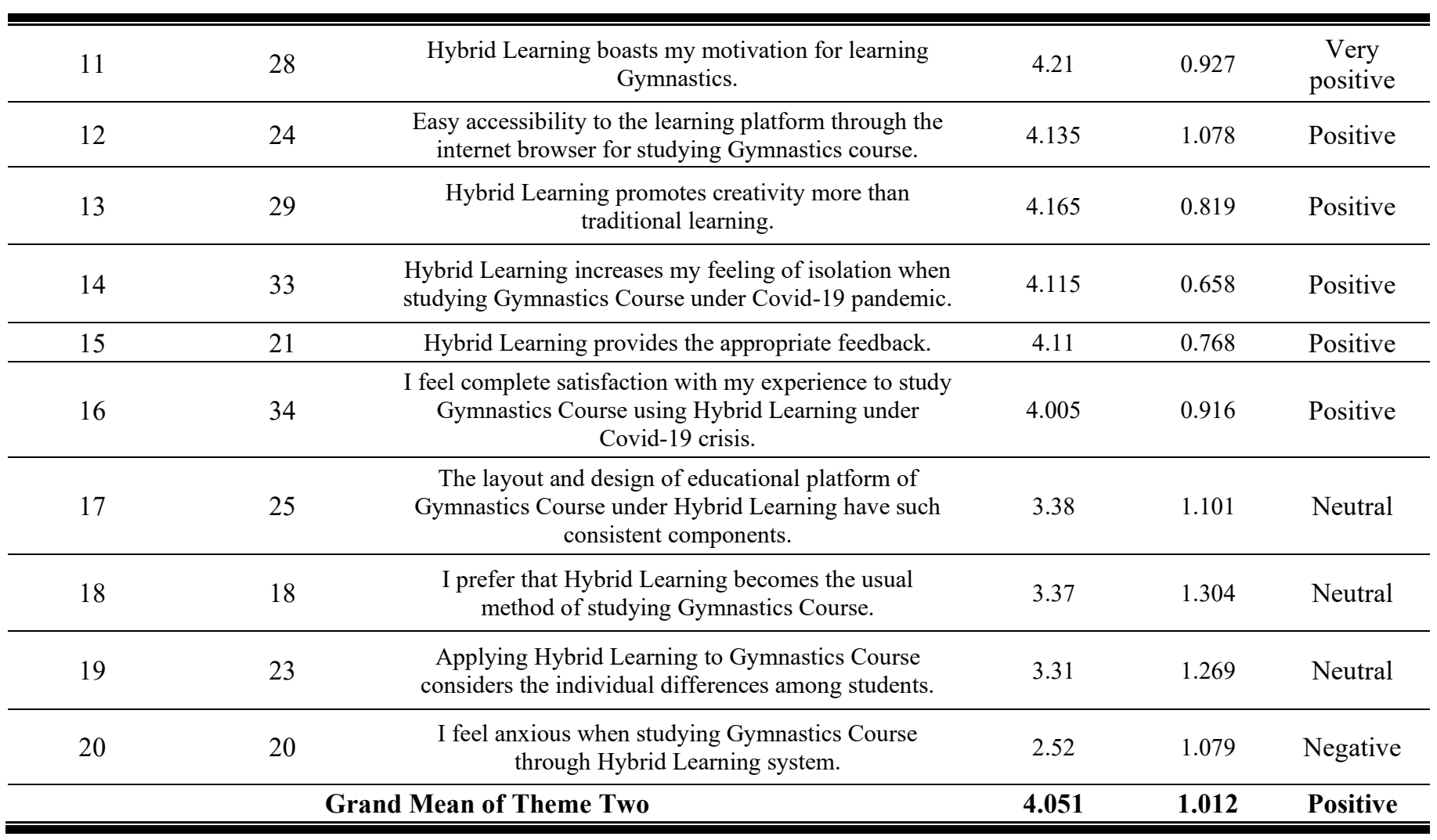

Table (2) shows that the individuals of study sample members have positive attitude and impressions towards the use of Hybrid Learning to Gymnastics Course with an arithmetic mean of (4.051 out of 5) located in the second category of the five-point scale (from 3.4 to less than 4.2), the category referring to "Agree" in the study tool. This demonstrates that the study sample members have a positive attitude towards Hybrid Learning.

Table (2) also shows that the score of students' attitudes to Theme Two phrases ordered from No. 1 to No. 11, were at the Very Positive level, since the arithmetic averages ranged between (4.575 to 4.21). These averages are located in the first category of the five-point scale, which indicates the Very Positive attitude and impressions of the study sample members towards the use of Hybrid Learning to Gymnastics Course.

The phrases ordered from No. 12 to No. 16 came at the positive level, where the arithmetic averages ranged between (4.135 to 4.005), as located in the second category of the five-point scale; the category that indicates the sample members' positive attitude and impressions towards the use of hybrid education to Gymnastics Course. This result can be explained in light of the video lectures provided by the Hybrid Learning for Gymnastics Course since they help student identify the important points of how to perform the prescribed skills. Therefore, students think that it is an effective way for studying Gymnastics Course under Covid-19 pandemic. This system increases students' interaction in video or college-based lectures as well.

Furthermore, students found that Hybrid Learning provides the appropriate reinforcement for studying Gymnastics Course, as they can replay the videos more than once and at their convenience. They may also obtain the necessary feedback during the college-based lectures. The e-exams for Gymnastics Course provide fair opportunities for evaluating all students when applying Hybrid Learning, as it is a new method of evaluation that has been added to teaching 
and learning strategy in the college. Hybrid Learning has also saved time for students owing to a week of college-based education followed by a week of e-learning.

Students have also found that applying Hybrid Learning to Gymnastics Course enhances their attainment since instructors use several methods in delivering the material with the diversity of learning resources. This contributes to the development of students' technological skills and strengthens their motivation towards Gymnastics Course. Moreover, students enjoy the easilyaccessible educational platform through internet explorer. The averages of students' responses to the negative phrase stating "Hybrid Learning arouses my feeling of isolation when studying Gymnastics Course under Covid-19 pandemic" were "4.115", which obtains 4 scores as a negative phrase when they choose "Disagree". This indicates their positive attitude towards Hybrid Learning and that it does not arouse their feeling of isolation upon studying Gymnastics Course under Covid-19 pandemic. In addition, it denotes that they feel complete satisfaction with studying Gymnastics Course using Hybrid Learning under Covid-19 pandemic.

Phrases ordered from 17 to 19 come at the Neutral Level since their arithmetic averages ranged from 3.38 to 3.31 , which are located at the third level of the five-point scale; the category referring to the neutral attitude and impressions towards the use of Hybrid Learning to Gymnastics Course. This can be explained by the fact that students' experiences in the layout and designs of educational platforms are still little since it is a new system never used by them before. In addition, they have not studied Gymnastics Course in the conventional way. They also have limited experiences whether Hybrid Learning observes the individual differences among students or not. Consequently, they are not able to identify whether they have positive or negative impressions towards these phrases.

Dziuban et al., (2018) indicates that Hybrid Learning is one of the most important elearning forms that has been widely used in recent times. It mixes the conventional face-to-face learning with e-learning, which research papers and studies have proven to be effective in providing efficient educational environments, promoting learning and realizing students' positive attitudes toward the same. (19:154)

Phrase 20 has obtained a negative attitude since the arithmetic mean was (2.52), which occupies the fifth category of the five-point scale; the category referring to the sample members' negative attitude and impressions towards the phrase, as caused by students' anxiety about studying Gymnastics Course as per Hybrid Learning system. This can be justified by the fact that it is a new system, and that the nature of Gymnastics Course with its various skills to be performed on various devices requires much training to acquire the confidence and courage. This unfortunately has not been completely attained due to the study system depending on one-week college-based learning, followed by one-week e-learning.

"Sabreen Mahmoud" (2021) states here that in spite of the numerous positives for elearning, the sudden transformation to remote teaching during Covid-19 period has caused a shock and anxiety for many students and teachers, whether personally or occupationally since the process requires redoubled efforts, along with the mental instability due to the epidemic outbreak. In addition, there are other non-ordinary obstacles in the path of students such as: lack of adequate time, poor infrastructure and inadequacy of the digital content. (8:210)

These results agree with the study of "Khaled Abdel Jaleel et al" (2017) (18), "Ebrahim Abdullah" (2021) (1), "Shaimaa Mostafa, Safinaz Muhammed Annabawi" (2021) (7) in forming a positive attitude towards Hybrid Learning as an easy form facilitating the learning process, and that most students have expressed a positive attitude towards Hybrid Learning for being more effective than traditional way of teaching for advancing knowledge and enhancing skills. 


\title{
Third: Review and Discussion of Theme Three Results
}

\author{
Table (3)
}

The Order of Phrases according to the Score of Students' Attitudes towards Theme Three Phrases "The Importance of using Hybrid Learning to study

Gymnastics Course"

\begin{tabular}{|c|c|c|c|c|c|}
\hline & & & & & 00 \\
\hline $\begin{array}{c}\text { Order } \\
\text { according } \\
\text { to the Score } \\
\text { of Attitude }\end{array}$ & $\begin{array}{c}\text { Phrase } \\
\text { Number in } \\
\text { Questionnaire }\end{array}$ & Phrases & $\begin{array}{l}\text { Arithmetic } \\
\text { Mean }\end{array}$ & $\begin{array}{l}\text { Standard } \\
\text { Deviation }\end{array}$ & $\begin{array}{l}\text { Attitude } \\
\text { Score }\end{array}$ \\
\hline 1 & 44 & $\begin{array}{l}\text { I can review what I learned in Gymnastics Course } \\
\text { more than once when using Hybrid Learning system }\end{array}$ & 4.635 & 0.594 & $\begin{array}{c}\text { Very } \\
\text { Positive }\end{array}$ \\
\hline 2 & 51 & $\begin{array}{c}\text { Hybrid Learning applied to Gymnastics Course does } \\
\text { not provide extra video lectures for discussion and } \\
\text { questions in all activities. }\end{array}$ & 4.61 & 0.499 & $\begin{array}{l}\text { Very } \\
\text { Positive }\end{array}$ \\
\hline 3 & 55 & $\begin{array}{l}\text { I encourage my mates to review the Gymnastics } \\
\text { Course through the accessible platform. }\end{array}$ & 4.485 & 0.625 & $\begin{array}{c}\text { Very } \\
\text { Positive }\end{array}$ \\
\hline 4 & 53 & $\begin{array}{l}\text { Hybrid Learning provides diversity in multimedia } \\
\text { "audio, picture, video" used in delivering the electronic } \\
\text { content in Gymnastics Course }\end{array}$ & 4.48 & 0.625 & $\begin{array}{l}\text { Very } \\
\text { Positive }\end{array}$ \\
\hline 5 & 39 & $\begin{array}{l}\text { Hybrid Learning provides me with additional learning } \\
\text { resources for Gymnastics Course. }\end{array}$ & 4.47 & 0.625 & $\begin{array}{c}\text { Very } \\
\text { Positive }\end{array}$ \\
\hline 6 & 54 & $\begin{array}{l}\text { I got much benefit from reviewing the Student Guide } \\
\text { for Applying Hybrid Learning in the College. }\end{array}$ & 4.47 & 0.51 & $\begin{array}{c}\text { Very } \\
\text { Positive }\end{array}$ \\
\hline 7 & 37 & $\begin{array}{l}\text { Hybrid Learning provides an enough opportunity for } \\
\text { practically applying the Gymnastics Course skills } \\
\text { during the college-based learning week. }\end{array}$ & 4.43 & 0.676 & $\begin{array}{c}\text { Very } \\
\text { Positive }\end{array}$ \\
\hline 8 & 48 & $\begin{array}{l}\text { I am able to answer questions and notes that professors } \\
\text { or colleagues add on the platform used to study } \\
\text { Gymnastics Course in Hybrid Learning system. }\end{array}$ & 4.425 & 0.505 & $\begin{array}{c}\text { Very } \\
\text { Positive }\end{array}$ \\
\hline 9 & 49 & $\begin{array}{l}\text { I am able to download all assignments and upload } \\
\text { answers to the platform used for studying Gymnastics } \\
\text { Course through Hybrid Learning system }\end{array}$ & 4.38 & 0.654 & $\begin{array}{l}\text { Very } \\
\text { Positive }\end{array}$ \\
\hline 10 & 42 & $\begin{array}{c}\text { Using Hybrid Learning system for studying } \\
\text { Gymnastics Course diminishes cooperation between } \\
\text { me and my colleagues. }\end{array}$ & 4.33 & 0.796 & $\begin{array}{c}\text { Very } \\
\text { Positive }\end{array}$ \\
\hline 11 & 41 & $\begin{array}{l}\text { I advocate the dissemination of the experience of using } \\
\text { Hybrid Learning in Gymnastics Course under Covid- } \\
19 \text { pandemic. }\end{array}$ & 4.285 & 1.058 & $\begin{array}{l}\text { Very } \\
\text { Positive }\end{array}$ \\
\hline 12 & 52 & $\begin{array}{l}\text { Hybrid Learning provides intense information for } \\
\text { Gymnastics Course }\end{array}$ & 4.2 & 0.722 & $\begin{array}{c}\text { Very } \\
\text { Positive }\end{array}$ \\
\hline 13 & 47 & $\begin{array}{l}\text { The platform used to study Gymnastics Course } \\
\text { through Hybrid Learning system lacks privacy }\end{array}$ & 4.175 & 0.876 & Positive \\
\hline 14 & 38 & $\begin{array}{l}\text { Hybrid Learning helped me find solutions to my study } \\
\text { problems in Gymnastics Course }\end{array}$ & 4.12 & 0.817 & Positive \\
\hline 15 & 45 & $\begin{array}{l}\text { I can do the educational activities better when I study } \\
\text { Gymnastics Course through Hybrid Learning system }\end{array}$ & 4.115 & 0.568 & Positive \\
\hline 16 & 40 & $\begin{array}{l}\text { Using Hybrid Learning to study Gymnastics Course } \\
\text { allows me to assume a bigger role in taking } \\
\text { responsibility for my education }\end{array}$ & 4.045 & 0.542 & Positive \\
\hline
\end{tabular}




\begin{tabular}{cccccc}
\hline \hline 17 & 43 & $\begin{array}{c}\text { Hybrid Learning provides another type of tests to } \\
\text { assess the level of performance in Gymnastics Course }\end{array}$ & 3.945 & 0.532 & Positive \\
\hline 18 & 50 & $\begin{array}{c}\text { I can download and record all lectures of Gymnastics } \\
\text { Course on the platform }\end{array}$ & 3.93 & 0.943 & Positive \\
\hline 19 & 46 & $\begin{array}{c}\text { Hybrid Learning provides me with skills coping with } \\
\text { labor market. }\end{array}$ & 2.58 & 1.179 & Negative \\
\hline & Grand Mean of Theme Three & $\mathbf{4 . 2 1 6}$ & $\mathbf{0 . 8 4 7}$ & $\begin{array}{c}\text { Very } \\
\text { Positive }\end{array}$ \\
\hline \hline
\end{tabular}

Table (3) shows that the study sample members have positive attitudes and impressions about the importance of using Hybrid Learning in Gymnastics Course with an arithmetic mean of (4.216 out of 5), which occupies the first category of the five-point scale (from 4.2 and above), referring to "Strongly Agree" option in the study tool. This indicates that the study sample members have a positive attitude towards Hybrid Learning.

Furthermore, Table (3) shows that the score of students' attitude towards Theme Three phrases ordered from 1 to 12 was at the very positive level since arithmetic means ranged from (4.635 to 4.2), which occupies the first category of the five-point scale; the category referring to the sample members' very positive attitude towards the usage and application of Hybrid Learning in Gymnastics Course.

Phrases ordered from 13 to 18 come at the positive level since the arithmetic means ranged from (4.175 to 3.93 ), which occupies the second category of the five-point scale; the category referring to the sample members' positive attitude towards the usage and application of Hybrid Learning in Gymnastics Course. This result can be explained in view of the fact that Hybrid Learning gives the opportunity to review what has been learnt more than once. The students' responses to the negative phrase stating that "Hybrid Learning system for Gymnastics Course does not provide extra lectures for discussion and questions in all activities" were "Strongly Disagree" attaining 5 scores as a negative phrase. This indicates their positive attitude towards Hybrid Learning, and that they provide extra lectures for discussion and questions on curriculum activities. They, moreover, encourage their colleagues to review Gymnastics Course through the accessible platform in order to get benefit from the diversity of multimedia "audio, picture, video" used in providing the electronic content for Gymnastics Course, and that students' usage of these extra learning resources help them increase their knowledge base.

The students also benefited from reviewing the Student Guide for Applying Hybrid Learning in the College, which includes the concept, objectives, requirements of Hybrid Learning, the college plan, time map, and the college's e-learning platforms to implement the Hybrid Learning system. Students were also able to practically perform skills during the collegebased week and benefited from instructors in gaining and improving the level of skill performance under Covid-19 pandemic and its challenges. In addition, they could participate effectively and upload assignments on the educational platform.

The students' responses to the negative phrase stating that "Using Hybrid Learning system for studying Gymnastics Course diminishes cooperation between me and my colleagues." were "Strongly Disagree" attaining 5 scores as a negative phrase. This indicates their positive attitude towards Hybrid Learning, and that they implement joint activities with their colleagues during their study. Accordingly, students advocate the dissemination of the experience of using Hybrid Learning in Gymnastics Course under Covid-19 pandemic. Students' responses to the negative phrase stating "The platform used to study Gymnastics Course through Hybrid Learning system lacks privacy" were "Strongly Disagree" attaining 4 scores as a negative phrase. This 
indicates their positive attitude and that they implemented various activities during their study, and found that it has privacy upon uploading or delivering any files or e-exams.

Many students who had academic problems in Gymnastics Course were able to find solutions through re-presenting and studying the material on the platform, and applying e-exams for Gymnastics Course for the first time. Here the educational process has become studentcentered, as the role she plays has increased, as well as the responsibility she assumes for her education.

Phrase ordered 19 comes at the negative attitude since the arithmetic mean was (2.58), which occupies the fourth category of the five-point scale; the category referring to the sample members' negative attitude since students found that Hybrid Learning did not enable them to acquire the skills coping with the labor market in Gymnastics Course. The researcher attributes this to the fact that the system is new, and to the students' poor experience in identifying the skills required in the labor market. This requires the persons in charge to exert more efforts in editing and addition for the electronic content.

In general, the researcher attributes the positive attitudes towards the use of Hybrid Learning in Gymnastics Course to the negative effects of Covid-19 pandemic on the educational process. Universities have been closed, study have been suspended, and students have been isolated at home and left their universities for a long time. This causes them to seek to complete their education and resume their study programs. This was evident in the positive attitudes towards Hybrid Learning, which provided them with the opportunity to resume their study through electronic learning platforms and college-based lectures.

"Mosheera Mahmoud" (2021) said that the advancement of modern information and communication technologies helped reconsider the structure of educational institutions to provide new environments and updated methods of education. This paved the way for the emergence of a new type of education that mixes between traditional education and e-learning, called Hybrid Learning. (14:608)

"Sinaa Qassem" (2021) states that Hybrid Learning is a mixture between e-learning and regular education, and therefore it does not overlook the emotional aspect of students. It also suits the freedom of movement restricted by precautionary conditions to limit the spread of the pandemic. Therefore, it should be included in the inputs of university education institutions in alignment with the requirements of the current situation and within the framework of the philosophy of higher education. (6:16)

These results agree with the study of "Fatima Aladwan" (2018) (20), "Ibrahim Abdullah" (2021) (1), "Shaimaa Mustafa, Safinaz Muhammad" (2021) (7), "Essa Muhammad" (2021) (11) in creating a positive attitude towards Hybrid Learning, as it is a method that facilitates the learning process under Covid-19. The electronic resources provided through Hybrid Learning are an effective way to help students acquire knowledge and improve their skills, and have a tremendous impact on students taking responsibility for their own learning process.

\section{Conclusions}

Based on the results of the questionnaire, it was concluded that there are attitudes among the students of the Faculty of physical Education towards the use of Hybrid Learning to study Gymnastics Course under Covid-19 pandemic, as follows:

1. The study sample members from the Faculty of Physical Education have a very positive attitude towards the First Theme phrases "Awareness of Hybrid Learning system for Gymnastics Course" with an arithmetic mean of (4.239 out of 5) placed in the first category of the five-point scale (from 4.2 or more); the category that indicates the "Strongly Agree" 
option in the study tool. This indicates that the study sample members have a positive attitude towards Hybrid Learning.

2. The study sample members from the Faculty of Physical Education have a very positive attitude towards the Theme Two phrases "Students' Impressions towards the Use of Hybrid Learning to Gymnastics Course" with an arithmetic mean of (4.051 out of 5) placed in the second category of the five-point scale (from 3.4 to less than 4.2); the category that refers to "Agree" option in the study tool. This indicates that the study sample members have a positive attitude towards Hybrid Learning.

3. The study sample members from the Faculty of Physical Education have a positive attitude and impressions towards the Three Theme phrases "The Importance of using Hybrid Learning to study Gymnastics Course" with an arithmetic mean of (4.216 out of 5) placed in the first category of the five-point scale (from 4.2 or more); the category that refers to "Strongly Agree" option in the study tool. This indicates that the study sample members have a positive attitude towards Hybrid Learning.

\section{Recommendations}

1. Relying on Hybrid Learning strategy for teaching Gymnastics during Covid-19 pandemic.

2. Develop the infrastructure, and provide all material and human equipment to help implement Hybrid Learning strategy.

3. Develop a plan to train all faculty members, students, and technicians who are supervising programs for implementing Hybrid Learning.

4. Monitor material and moral incentives to activate Hybrid Learning in teaching.

5. Educate students about the importance of Hybrid Learning.

6. Design electronic courses, taking into account the needs and characteristics of learners.

7. Provide budgets to support the activation of Hybrid Learning in the faculties of physical education.

\section{Resources}

\section{First: Arabic Resources}

1. Ebrahim Abdullah Mohammed (2021): " "The reality of using hybrid education in teaching students of the Department of Geography at the Faculty of Education, Kafr El-Sheikh University from their point of view", Faculty of Education, Al-Azhar University, Issue 189, Volume 2.

2. Eman Abdulhakim Refaei (2021): "A proposed ethical charter for the university community in light of the application of hybrid learning at the Faculty of Early Childhood Education Minia University as a model ", Childhood and Education Magazine, Issue 45, Volume 13, Faculty of Education Early Childhood, University of Alexandria.

3. Tayseer Al-Kilani (2011): Blended Learning Strategies, Series of publications for the Arab Network for Open and Distance Education, Bookshop of Lebanon.

4. Gomaa Hassan Ebrahim (2010): " "Attitudes of educational qualification diploma students at the Syrian Virtual University towards e-learning and its relationship to gender, specialization, computer experience and computer training courses: a survey study. ", Association of Arab Universities Journal for Education and Psychology, Issue 2, Volume 8, Faculty of Education, Damascus University.

5. Rajaa Mahmoud Abu Allam (2006): Research methods in psychological and educational sciences, Print 5, Dar An-Nashr for Universities, Cairo. 
6. Sinaa Qasim Ahmed (2021): "Hybrid education and quality assurance of higher education in the Republic of Yemen in light of the Corona pandemic", Issue 21, Faculty of Education Research Papers, Hodeidah University.

7. Shaimaa Mostafa Abdulaziz, Safinaz Mohammed Al-Nabawi 2021: "Benefiting from hybrid education in raising the skills of students in the course of detail and knitting under the Corona pandemic", Issue 33, Volume 1, Al-Bohouth Magazine in Specific Education Fields, Faculty of Specific Education, Minya University.

8. Sabreen Mahmoud Al-Salman (2021): Attitudes of basic and secondary education students in Jordan towards distance learning and its challenges in light of the Corona pandemic", International Magazine for Educational and Psychological Studies, Volume 9, Issue 1, Rafad Center for Studies and Research Papers.

9. Tareq Kamal (2006): basics of general psychology, Print 1, Shabab Institution for Publication and distribution, Alexandria.

10. Abdullah Kabid Shakheer (2021): ""The reality of the trends of students of the College of Basic Education towards the use of distance education in light of the Corona pandemic" , Childhood and Education Magazine, Volume 13, Issue 45, Faculty of Education for Early Childhood, Alexandria University.

11. Eisa Mohammed Albalhan, Abdulmotalib Abdulqadir Abdulmotalib (2021): "Students' attitudes towards distance education compared to direct education to confront the Corona virus (Covid 19) and its relationship to psychological adjustment" , Issue 138, Volume 35, Educational Magazine, Scientific Publication Council, Kuwait University.

12. Magdy Ali Zamel (2012): Attitudes of female students of the College of Educational Sciences towards blended learning after studying blended university courses. Arab Universities Association Magazine, Issue 59.

13. Mahmoud Al-Said Abu Al-Nil (2009): " "Social Psychology, Arab and International, Print 5, Anglo Egyptian Bookshop, Cairo.

14. Mosheera Mahmoud Ahmed (2021): "A proposed conception from the perspective of the way of organizing society to achieve the requirements of the quality of hybrid education in institutions of social work education.", Issue 53, Volume 3, Magazine of Studies in Social Service and Human Sciences, Helwan University.

15. Mostafa Ahmed Abdullah (2020): "A proposed conception for the application of hybrid education in general secondary schools in Egypt in light of the new Corona pandemic" Fayoum University Magazine for Educational and Psychological Sciences, Issue 14, Volume 7, Faculty of Education, Fayoum University.

\section{Second: English Resources}

16. Allport, Gorden. (2009). Attitudes, Handbook of Social Psychology, Worcester, Vol. 18, No. 3.

17. Dowering. A. (2006). (A. Adventure Learning Transformative Hybrid Online Education Distance. Education ,27(2),197-215.

18. Dweikat, Khaled Abdel Jaleel et al, (2017): Students' Attitudes Towards Blended Learning at Al Quds Open University, Journal of Al-Quds Open University for Humanities and Social Studies, Vol 42.

19. Dziuban, C.; Graham, C; Patsy M.; Norberg A. and Sicilia, N. (2018). Blended learning: the new normal and emerging technologies. International Journal of Educational Technology in Higher Education, 15(3). 
20. Fatima Aladwan et al (2018): Students Attitudes toward Blended Learning among students of the University of Jordan, Modern Applied Science, Vol. 12, No. 12.

21. Jahren, C., Karabulut, A., Jeong, H.\&Cormicle L. (2015): A case study of hybrid learning implementation in construction engineering. 5th international $/ 11$ th construction specialty conference, At Vancouver, British Columbia, Canada.

22. Karaaslan, Hatice; Kiliç, Nurseven, (2019): Students' Attitudes towards Blended Language Courses: A Case Study, Journal of Language and Linguistic Studies, v15 n1 p174-199.

23. Slavkin, M, Reasons, C., Valadares, K. (2005). Questioning the Hybrid Model: student outcomes in different courses formats. JALN, 9(1) available on http://www.sI;anc.org \publicatioons \jaln\uqn-reason.a

Third : information network sites Resources

24. https://www.new-educ.comTeaching-and-learning-in-the-shadow of Corona/ 